FACTA UNIVERSITATIS

Series: Philosophy, Sociology, Psychology and History Vol. 20, № 2, 2021, pp. 97 - 111

https://doi.org/10.22190/FUPSPH2102097V

Review Paper

\title{
CHILDBIRTH POSTPONEMENT AND AGE-RELATED INFERTILITY IN SERBIA
}

\author{
UDC 314.12(497.11)
}

\section{Petar Vasić}

University of Belgrade, Faculty of Geography, Department of Demography, Serbia

\begin{abstract}
Childbirth postponement has been a widely discussed topic since the 1990s, and was pushed to the top of the demographic agenda with the emergence of the Second Demographic Transition (SDT) paradigm. Mechanisms of childbirth postponement mostly explained by economists or sociologists were understood as rational-based decisions of individuals (or couples) trying to cope with the requirements of modern society. These mechanisms explained by income and consumption rationale (Becker, Modigliani), or by liberal and postmodern values (Van de Kaa, Lestheage), barely mention the physiological limitations of the individual choice. These limitations given by the human species reproductive span, with no exception, affect everyone trying to make an optimal reproductive choice. There are two main effects of fertility postponement on births and fertility rates. The first effect arises when couples postpone childbearing to a later age during a certain period and fewer births take place than in the absence of such postponement - the 'tempo effect'. The second is a negative effect of fertility postponement on completed fertility and increased childlessness attributable to the age-related increase in infertility. This second negative effect in particular is our field of interest. The decline in cohort fertility due to postponement has been mostly studied using data on age at first birth and subsequent fertility, as well as models of fecundity, pregnancy loss and time to conception by age, which we will try to apply to the period data. Using period data, we will try to quantify the potential number of births that would occur in the absence of childbirth postponement in Serbia during the past two decades.
\end{abstract}

Key words: childbirth postponement, fertility tempo, infertility, fetal loss, success rate.

Received September 24, 2020 / Accepted November June 4, 2020

Corresponding author: Petar Vasić

University of Belgrade, Faculty of Geography, Studentski trg 3, 11000 Belgrade, Serbia

E-mail: vasic.dem@gmail.com

(๑) 2021 by University of Niš, Serbia | Creative Commons License: CC BY-NC-ND 


\section{INTRODUCTION}

Childbirth postponement has been a widely discussed topic since the 1990s, and was pushed to the top of the demographic agenda with the emergence of the SDT paradigm. Mechanisms of childbirth postponement mostly explained by economists or sociologists were understood as rational-based decisions of individuals (or couples) trying to cope with the requirements of modern society. Modern contraception, especially the contraceptive pill spreading since the late 1960s, vastly improved women's abilities to plan their pregnancy and postpone childbearing to a later age (Goldin and Katz 2002; Van de Kaa 2011). Women may now enjoy a long period of a sexually active life, little affected by the fear of becoming pregnant (Schmidt et al. 2012). In western, southern and northern Europe as well as Japan the mean age of first-time mothers reached around 28-29 years in 2008, an increase of 4-5 years when compared to the 1970s (Schmidt et al. 2012). These mechanisms explained by income and consumption rationale (Becker, Modigliani), or by liberal and postmodern values (Van de Kaa, Lestheage), barely mention the physiological limitations of the individual choice. These limitations given by the human species reproductive span, with no exception, affect everyone trying to make optimal reproductive choice.

There are two main effects of fertility postponement on births and fertility rates. The first effect arises when couples postpone childbearing to a later age during a certain period and fewer births take place than in the absence of such postponement, the socalled 'tempo effect'. The second is the negative effect of fertility postponement on completed fertility and increased childlessness attributable to the age-related increase in infertility (Schmidt et al. 2012). This second negative effect in particular is our field of interest. Completed/cohort rates of fertility can be measured only after one generation exits the reproductive period. However, there may be a way to measure fertility decrease attributable to age-related increase in infertility due to childbirth postponement using period data. The biggest issue would be to define the benchmark (success probability curve) for measuring the infertility tempo effect (ITE). As the age pattern of fertility is changing, shifting median age at birth (MAB) to later age, and increasing the impact of age-related infertility, the total number of livebirths decreases.

\section{THE AIM OF THE PAPER AND METHODOLOGY}

The main and final aim of the paper is to quantify the effect of age-related infertility on the total births in Serbia. Regarding the main aim, the specific goals are to identify age-specific patterns of male and female infertility, and fetal loss. These specific goals will enable us to construct an age-specific probability curve as the main restriction to the realization of all fertility (live-birth) attempts. The basic assumption is that success probability decreases with a woman's age. All, male and female infertility, and fetal loss rates have their opposites, i.e. male and female fertility, and livebirth rates. The result of the multiplication of these rates will be the success rate which is highly negatively correlated with a woman's age.

In this paper we will analyze data on fertility in Serbia from 2001 to 2018. The reasons for such a time period are numerous, but two of them are crucial. First, 2001 is the first year to provide all the needed data, and second, 2018 is the latest available year in the Demographic yearbook in Republic of Serbia. Period data are extracted and calculated from the Demographic Yearbook of Republic of Serbia, and the EUROSTAT 
database. The demographic method based on period analysis (versus cohort analysis) will be used for the calculation of age-specific fertility rates, and fertility loss based on a woman's age. Since we have no reason to presume that the infertility pattern will differ for particular subpopulations within the Republic of Serbia, the analysis will be conducted on the total (fertile age women) population of Serbia.

\section{FERTILITY RESTRICTIONS}

\subsection{The age pattern of infertility}

As we discussed previously, male and female infertility may be considered as the main restriction to their reproductive goals. Yet, regarding different human fertility studies data (Dunson et al. 2004; Liu and Case 2011; Eijkemans et al. 2014), we cannot be sure about which part refers to permanent sterility, and which to infertility (subfertility). ${ }^{1}$ Although permanent sterility ${ }^{2}$ may be the first and basic restriction to reproductive goals, we cannot dare claim which part of unsuccessful attempts are ascribed to permanent sterility, and which part are ascribed to infertility defined in previous way. On the other hand, some studies developed models of age-related permanent sterility (Leridon 2008; Eijkemans et al. 2014), and their data are well documented and based on historical populations, yet, we can suspect that applying both rates would duplicate the values of permanent sterility rates. In the end, considering other studies conclusions about the inability to separate permanent sterility from infertility data, we will consider infertility data as the sum of permanent sterility and infertility.

The share of infertile women out of fertile women trying to conceive will be expressed by the pregnancy rate - PR, and consider PR as an indicator referring to the share of women able to conceive during one year (12 months) including permanently sterile women too. In other words, we will interpret PR as the share of women who succeeded to get pregnant within 12 months of trying, out of all women trying to conceive. Also, just like the woman's age is relevant, the man's age is relevant too. As we referring to man's ability to impregnate his female partner, we will name the share of men successfully impregnating their females as the impregnation rate - IR.

\subsubsection{Female infertility}

A woman's age is a strong factor influencing PR. For example, some studies on donor insemination confirm an age-related decline in pregnancy rates. These studies were performed in couples with severe male factor infertility, so can be considered to be a good reflection of female fertility because non-reproductive factors such as coital frequency are removed (Liu and Case 2011). Removing other factors, besides a woman's age, enables us to analyze age-related infertility. Liu and Case (2011) have researched literature on this issue and found that a negative effect on pregnancy rates is seen in women above the age of 30 , and is even more pronounced for women above the age of

\footnotetext{
${ }^{1}$ The usual medical definition of infertility is when couple fails to conceive after 12 months of trying. Some couples may be classified as clinically infertile based on not conceiving after a year or more of unprotected intercourse, but it is relatively unlikely that these couples are truly sterile and will be unable to conceive a pregnancy naturally if attempting for a longer interval. (Dunson et al. 2004).

${ }^{2}$ The real and life-long inability to conceive.
} 
35. They say that one study of almost 3000 cycles showed cumulative pregnancy rates of $62 \%$ for women below 30 years of age, and $44 \%$ for women aged $30+$ years after 12 cycles, and stress out that younger women often conceive quickly, and more cycles of treatment were often needed for women aged 35+ years (Doyle et al. 1993; Virro and Shewchuk 1984; according to Liu and Case 2011). Postponing attempts to achieve parenthood to an advanced reproductive age is associated with increased risk of infertility, prolonged time to pregnancy (TTP) and a range of adverse pregnancy outcomes (Schmidt et al. 2012). Results in studies examining 12 months' conception rates are different, but at the same time very similar. So, some studies reported that within 12 months, almost $90 \%$ of 20-28-year-old women, but only $75 \%$ of women around the age of 35 had achieved pregnancy (Schmidt et al. 2012), and according to Dunson et al. (2004) women aged 19-26 years achieved 92\%, women aged 27-34 years 86-87\%, and women aged 35-39 years achieved $88 \%$ pregnancy during one year. Women 35 years old were 2,2-fold more likely to be sub-fertile than women 25 years old (Hassan and Killick 2003). At any age over 30, women who have never conceived before have a lower probability of achieving a pregnancy (Steiner and Jukic 2016). On the other hand, Steiner and Jukic (2016) found that the overall conception (pregnancy) rate was 78\%, and dropped from $87-88 \%$ to $48 \%$ with the women's age. Age-associated infertility appears to be primarily related to ovarian aging (Liu and Case 2011, 1169). Other authors also stress that female age is the only realistic information available at present for estimating the magnitude of the reproductive ageing process (Eijkemans et al. 2014; Leridon 2004; Dunson et al. 2004; Wesselink et al. 2017). The steep rise in the number of ART (Artificial Reproductive Treatment) cycles at later reproductive ages clearly illustrates the scale of infertility and unfulfilled pregnancy desires among women who arguably postponed parenthood for too long (Beaujouan and Sobotka 2017). The biological ALB (Age at Last Birth) curve demonstrates that the average chance of involuntarily childlessness slowly increases to $12 \%$ at 35 and $20 \%$ at age 38 . From there this chance sharply rises to $50 \%$ at about 41 and reaches almost $90 \%$ at age 45 (Eijkemans et al. 2014). In her study, Wesselink et al. (2017) found that cumulative pregnancy proportion at 12 cycles of attempt time ranged from $79.3 \%$ (age 25-27 years old) to $55.5 \%$ (age 40-45 years old). In other words, women aged 40-45 had approximately $3 / 4$ the probability of conceiving within 12 cycles than did women 21-24 years old. Different data from studies researching noncontraceptive natural fertility populations have shown that marital fertility rates decline with increasing female age, with peak in the early to midtwenties and a steady decline at older ages (Wesselink et al. 2017; Eijkemans et al. 2014; Leridon 2008).

\subsubsection{Male infertility}

There is no doubt that pregnancy rate during a 12-month time frame is highly related to the women's age, but the male partner's age has certain influence too. Facts shown in previous texts represent adjusted data, i.e. data when controlled for male partner age, and other factors. Studies were conducted with the aim of explaining the effect of female aging on achieving pregnancy. Other studies show the effect of male age on achieving pregnancy during a 12-month time frame. Although significant focus has been placed on female reproductive aging, there is also an age-related decline in sperm function and male fertility. Although "andropause" is not a clearly defined event for men as menopause is for women, there is a decline in testicular function, which includes declining testosterone 
levels each year (McLachlan 2000 according to Liu and Case 2011). Among men the chances of achieving successful conception are less affected by age. However, advanced male age is an independent risk factor of reduced fecundability and prolonged time to conception. When analyzing age-related pregnancy rates during a 12-month time frame, Wesselink et al. (2017) pointed out that similar patterns were observed among male patients, although differences between age groups were smaller. Ford et al. (2000) reported that men 35+ years of age had twice the likelihood of subfecundity than men below 35 years of age. Olsen et al. (1990) found that the risk of subfecundity for men 40+ years of age was 30\% higher than that of men 15-19 years of age after adjustment for the female partner's age (according to Kidd et al. 2001). Liu and Case (2011) state that some studies find that sperm parameters including semen volume, motility, and morphology decrease with age, and that the odds of conception decrease 3\% per year. An analysis of the impact of male age on their partner becoming pregnant within 12 months showed the decreasing odds ratios even when controlled for the woman's age, when compared to the age group of 24-year-olds. The odds ratio for a conception within 12 months leading to a birth decreased by $3 \%$ per year of increasing male age, starting from age 25 (Ford et al. 2000). One cohort study (Pinborg et al. 2011) following couples in ART treatment found that each year of increase in male age reduced the probability of achieving a live birth approximately by $4 \%$ (median probability 0,96 ), when controlled for female age. The age of the man also has a large effect on TTP and the proportion of couples classified as clinically infertile. For men younger than 35, there is no effect, but starting in the late 30s, the impact of male age becomes pronounced. In particular, among 35-year-old women, the proportion of couples failing to conceive within 12 cycles increases from $18 \%$ if the male partner is 35 years old to $28 \%$ if the male partner is 40 (Dunson et al. 2004). Conception rates within 12 months decline significantly with increasing men's age. A fivefold increase in TTP occurred with men aged 45 compared to men aged 25, independent of the women's age, coital frequency, and life-style effect, as well as the effect of other subfertility risk factors. The odds ratios for men taking less than one year to impregnate their partners fall significantly in older men, whether the age at conception or at the onset of attempting to achieve pregnancy was used in the analysis.

Although male age-related sterility and infertility rates are not our main focus, it must be noticed that the male partner's age has a significant role in forming success rate values, so we have to pay attention to the couple's age difference. It is common in western (Christian) cultures that the male partner is slightly older than the woman. Men and women are delaying marriage and parenting to a similar extent, so the age difference between them remains almost identical. Men have delayed having children to an extent similar to women and remain on average about 3 years older than women when having a child (Schmidt et al. 2012), which stands for Serbia too. That pattern of, on average, 3-year older male partners showed as remarkably persistent behavioral model when speaking about marriage and procreation in Serbia. So, according to the 1900 census, the average age of the husband was 39,5 and the average age of the wife was 35,9 leading to 3,6-year age difference (State Statistics Administration of the Kingdom of Serbia 1905). The social conditions of that time dictated universal marriage and directly affected the level of fertility rates (Jovanović-Batut 1932). It is very indicative that the latest available (20022010 average) age difference between men and women when having a child in Serbia is still similar (3,8-year-older men) after more than a century. Also, even the average age difference between partners in non-marital unions is slightly above 3 years (Statistical 
Office of the Republic of Serbia 2017). Intending to quantify the effect of male agerelated infertility on success rates, we first have to identify age-specific age difference (measured by the woman's age) between men and women when having a child in Serbia. According to data from the Demographic Yearbook of the Republic of Serbia (20022010), showing live births by age of mother and father, we can calculate a smoothed average age difference to identify the age pattern of parents in Serbia (Table 1).

Table 1 Average age of father by age of mother at childbirth

\begin{tabular}{lcccccccccc}
\hline Age of mother & 2002 & 2003 & 2004 & 2005 & 2006 & 2007 & 2008 & 2009 & 2010 & Average \\
\hline $15-19$ & 25.0 & 25.0 & 24.9 & 25.0 & 24.9 & 24.7 & 24.9 & 24.8 & 24.8 & 24.9 \\
$20-24$ & 27.5 & 27.5 & 27.5 & 27.8 & 27.8 & 27.8 & 27.7 & 27.9 & 28.0 & 27.7 \\
$25-29$ & 30.8 & 30.8 & 30.9 & 31.0 & 31.1 & 31.1 & 31.1 & 31.1 & 31.2 & 31.0 \\
$30-34$ & 34.7 & 34.5 & 34.5 & 34.7 & 34.7 & 34.6 & 34.7 & 34.8 & 34.7 & 34.7 \\
$35-39$ & 39.0 & 39.0 & 42.4 & 39.1 & 38.9 & 38.9 & 38.8 & 38.6 & 38.5 & 39.2 \\
$40-44$ & 42.5 & 42.2 & 43.2 & 42.7 & 46.0 & 43.0 & 42.6 & 42.5 & 42.5 & 43.0 \\
$45-49$ & 43.4 & 42.2 & 44.6 & 40.8 & 43.2 & 45.0 & 44.2 & 44.9 & 45.7 & 43.8 \\
$50+$ & 38.6 & 39.4 & 40.8 & 30.3 & 39.8 & 34.2 & 37.3 & 42.5 & 41.8 & 38.3 \\
\hline
\end{tabular}

Source: Authors calculations based on data from the Demographic Yearbook of the Republic of Serbia 2002-2010.

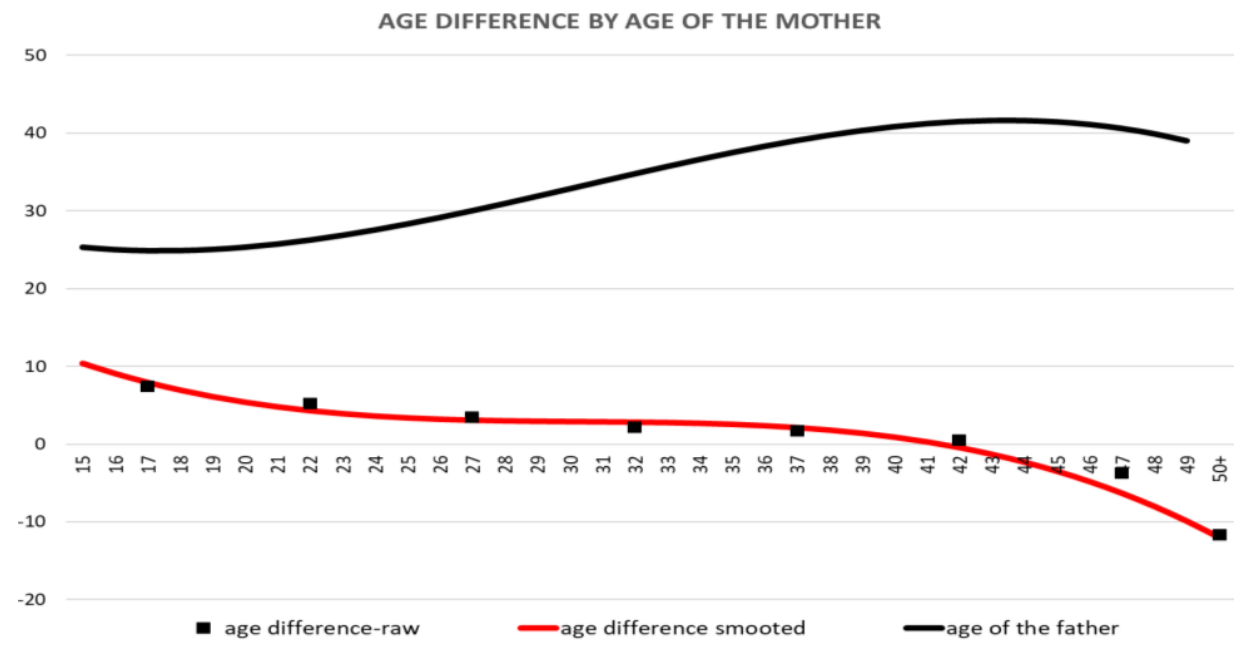

Fig. 1 Age difference between parents when having a child, by the mothers' age

Equation 1 Smoothed age difference - parabolic function

$$
A D_{x}=-0.0019 x^{3}+0.0936 x^{2}-1.5708 x+11.83
$$

Now, when we have identified the common age profile of the male partner in Serbia it would be useful to identify the average age-specific infertility in men. In the same way as we did in the case of female infertility, we will use findings presented above. Some of them say that the odds of conception decrease 3\% per year (Liu and Case 2011) from the 
age of 25 (Ford et al., 2000; according to Schmidt et al., 2012), and others say each year of increase in male age reduces the probability of achieving a live birth approximately by $4 \%$, when controlled for female age (Pinborg et al. 2011). Dunson et al. (2004) found that male age when the woman is 35 -year-old, influenced the proportion of couples failing to conceive within 12 cycles by approximately 2,5\% each year from 35 to 40 years of age of the male partner. Based on these findings, between 2,5\% and $4 \%$ of conception odds decreasing after the age of 24 and onwards, we decided to use median value of a $3 \%$ decrease and calculated the age specific male impregnation rates. It is important to stress that IR among men younger than 25 years of age was considered as a maximum when controlled for the woman's age, thus it is set at $100 \%$ (Table 2).

As women in general have partners who are several years older than them, it is important to focus more on the combined effect of advanced female and advanced male age on reproductive outcomes in the future (Schmidt et al., 2012). The great importance of the age of the partners at conception time point is supported by fact that ART makes up for only half of the births lost by postponing a first attempt at pregnancy from the age of 30 to 35 years, and <30\% after postponing it from 35 to 40 years (Leridon 2004). Postponement of childbearing increases the risk of infertility and the necessity of fertility treatment in order to achieve parenthood which, however, has a limited success rate at older ages (Schmidt et al. 2012). Thus, changes in the age pattern of fertility play a significant role in the explanation of the fertility decline in Serbia.

\subsection{The age pattern of fetal loss}

Beside the above-mentioned restrictions, fetal loss appears to be the last, but not less important restriction. Out of all the achieved conceptions/pregnancies not all of them will result in live births. Miscarriage rates increase with age. Therefore, age-associated decrease in live-birth rates may be due to both the decline in pregnancy rates and the increase in miscarriage rates with aging (Steiner and Jukic 2016). Also, paternal age > 40 does appear to be associated with risk of spontaneous abortion, even when maternal age is controlled for (Kleinhaus et al. 2006; Maconochie et al. 2007; according to Liu and Case 2011). Advanced maternal age was a significant risk factor for spontaneous abortion irrespective of the number of previous miscarriages, parity, or calendar period. Increasing risk was documented both after natural conception and after assisted conception (Schmidt et al. 2012). Nybo-Andersen et al. (2000) stress that, although maternal age is highly correlated with parity and reproductive history, their data showed a strong and independent effect of maternal age on the risk of spontaneous abortion.

Among women undergoing non-donor ART in 2013, pregnancy rates per cycle reached $46 \%$ at ages below $35,25 \%$ at age 40 and only $4 \%$ at ages $45+$. Because of high rates of miscarriage at higher ages, the fall in the likelihood of live-birth following the ART cycle is even steeper with age: $40 \%$ of non-donor ART cycles initiated at ages $<35$ resulted in live births in 2013, compared to $17 \%$ of the cycles initiated at age 40 and $2 \%$ at ages 45+ (Beaujouan and Sobotka 2017). Studies on spontaneous conceptions as well as assisted conceptions show that the risk of spontaneous abortions remains relatively stable up to a maternal age of 35 years. From age 35 to age 40 the abortion rate increases from around 15 to $30 \%$, and a rate of 50\% is reached at around 42 years of age. Thus, in relation to spontaneous abortion, a delay in the female childbearing age of up to around 35 years of age will have no significant impact, but the rate doubles over the next 5 -year 
age interval (Schmidt et al. 2012). Some other research found that the share of miscarriages grew from $13.6 \%$ at ages $25-29$, to $16.0 \%$ at ages $30-34,20.0 \%$ at ages $35-39$ and $27.0 \%$ at ages $40-44$ (Leridon 2004). Overall, $13.5 \%$ of the pregnancies intended to be carried to term ended with fetal loss. The risk of fetal loss according to maternal age at conception followed a J-shaped curve, with a steep increase after 35 years of age. More than one fifth of all pregnancies in 35-year-old women resulted in fetal loss, and at 42 years of age more than half of the intended pregnancies $(54.5 \%)$ resulted in fetal loss. Also, the risk of a spontaneous abortion was $8.9 \%$ in women aged $20-24$ years and $74.7 \%$ in those aged 45 years or more (Nybo-Andersen et al. 2000). For calculating livebirth rates (LR), we used data from above mention studies (Table 2).

\section{Defining the SuCCEss ProbabiLITy CURVE}

The success probability curve, should represent the joint age-specific influence of three mentioned fertility restrictions. These three restrictions are permanent sterility, (male and female) infertility, and fetal loss, which are embodied by the fecundity rate, impregnation rate (males) (IR), pregnancy rate (females) (PR), and live-birth rate (LR). Previously we have mentioned that data often show infertility including permanent sterility, so we are going to use infertility data only, to avoid duplication of permanent sterility restriction. When we are observing infertility only, we must stress that infertility restriction is the result of both male and female factors (IR*PR), and that the specific age pattern of partner unions (parents) in Serbia is of noticeable significance. These restrictions act jointly in the following way. Out of, for example, 1000 women 900 of them will get pregnant over 12 months (which may be considered as one calendar year) (1000*IR*PR), and out of these 900 pregnant women, 700 will give birth to a live child (900*LR). All of these rates change during the reproductive life of a woman, so that the age structure of mothers will be the main factor shaping the average success rate in a particular population. The success probability curve shows changes in success rate values during the reproductive life of women (15-49) in the human population, but will differ in different populations only if the age pattern of partner unions is different (age-specific age difference between the mother and father of a child). So, the success probability curve to be shown is for Serbian data only.

Further, we may observe these restrictions in different points of time in which the age of the woman will differ, so we must decide which time point to use. These time points are the age when attempts (to conceive) have started, the age when conception occurred, and age at the time of labor. To know the time when the attempts started we must have a precise time to pregnancy (TTP) interval which we do not know, so this time point is off. The chronological order goes from attempting to start, pregnancy, and childbirth, so the only precise time point that we have is the last one. On the other hand, a woman is aging during mentioned time lapse, so choosing the start of pregnancy (conception point) seems to be the best approximation for measuring the success rate. In that manner, we will adjust all rate values to the conception age (childbirth time point minus 9 months). The general idea for adjusting rates to the conception time point was that only $25 \%$ of all livebirths in one calendar year are actually conceived in that year due the 9-month duration of pregnancy (Equation 2). 
Equation 2 General adjustment formula $(\mathrm{R}$ - rate)

$$
\operatorname{adj} R_{x}=R_{x} * 0.25+R_{x-1} * 0.75
$$

Table 2 Age-specific success rate in Serbia

\begin{tabular}{|c|c|c|c|c|}
\hline Age & $\operatorname{adjPR} R_{x}$ & $\operatorname{adjIR}_{x}$ Serbia & $\operatorname{adjLR}_{x}$ & $\operatorname{adjSR}_{x}$ (Age factor) \\
\hline 15 & 78.8 & 95.8 & 79.7 & 60.2 \\
\hline 16 & 80.3 & 96.5 & 82.0 & 63.6 \\
\hline 17 & 81.7 & 97.1 & 84.1 & 66.7 \\
\hline 18 & 82.8 & 97.3 & 85.9 & 69.3 \\
\hline 19 & 83.8 & 97.2 & 87.6 & 71.3 \\
\hline 20 & 84.7 & 96.7 & 89.0 & 72.8 \\
\hline 21 & 85.3 & 96.2 & 90.1 & 74.0 \\
\hline 22 & 85.8 & 95.5 & 91.1 & 74.6 \\
\hline 23 & 86.2 & 94.6 & 91.8 & 74.8 \\
\hline 24 & 86.4 & 93.5 & 92.3 & 74.5 \\
\hline 25 & 86.4 & 92.4 & 92.5 & 73.8 \\
\hline 26 & 86.2 & 91.1 & 92.6 & 72.7 \\
\hline 27 & 85.9 & 89.6 & 92.4 & 71.1 \\
\hline 28 & 85.4 & 88.1 & 92.0 & 69.2 \\
\hline 29 & 84.7 & 86.6 & 91.3 & 67.0 \\
\hline 30 & 83.9 & 85.1 & 90.4 & 64.6 \\
\hline 31 & 82.9 & 83.4 & 89.3 & 61.8 \\
\hline 32 & 81.8 & 81.9 & 88.0 & 59.0 \\
\hline 33 & 80.5 & 80.3 & 86.5 & 55.8 \\
\hline 34 & 79.0 & 78.7 & 84.7 & 52.7 \\
\hline 35 & 77.3 & 77.1 & 82.7 & 49.3 \\
\hline 36 & 75.5 & 75.8 & 80.4 & 46.0 \\
\hline 37 & 73.6 & 74.5 & 77.9 & 42.7 \\
\hline 38 & 71.4 & 73.2 & 75.3 & 39.3 \\
\hline 39 & 69.1 & 72.1 & 72.3 & 36.0 \\
\hline 40 & 66.6 & 71.1 & 69.2 & 32.8 \\
\hline 41 & 64.0 & 70.3 & 65.8 & 29.6 \\
\hline 42 & 61.2 & 69.7 & 62.2 & 26.5 \\
\hline 43 & 58.2 & 69.4 & 58.4 & 23.6 \\
\hline 44 & 55.1 & 69.2 & 54.3 & 20.7 \\
\hline 45 & 51.8 & 69.3 & 50.0 & 18.0 \\
\hline 46 & 48.3 & 69.6 & 45.5 & 15.3 \\
\hline 47 & 44.7 & 70.2 & 40.8 & 12.8 \\
\hline 48 & 40.9 & 71.3 & 35.8 & 10.4 \\
\hline 49 & 36.9 & 72.5 & 30.6 & 8.2 \\
\hline
\end{tabular}

Source: Author's calculations based on data from Nybo Andersen et al. 2000; Ford et al. 2000; Dunson et al. 2004; Leridon 2004; Liu and Case 2011; Pinborg et al. 2011; Schmidt et al. 2012; Steiner and Jukic 2016; Wesselink et al. 2017.

The previous table (Table 2) shows adjusted values of age-specific IR, PR, LR, and the success rate (SR) which are calculated as average values of data from various studies, and smoothed to single year ages (original data were often showed as five or larger age 
groups) by a quadratic function ${ }^{3}$. Finally, age-specific success rate adjusted to conception point would be the result of the multiplication of three restrictions: adjusted pregnancy rate, adjusted impregnation rate, and adjusted live-birth rate.

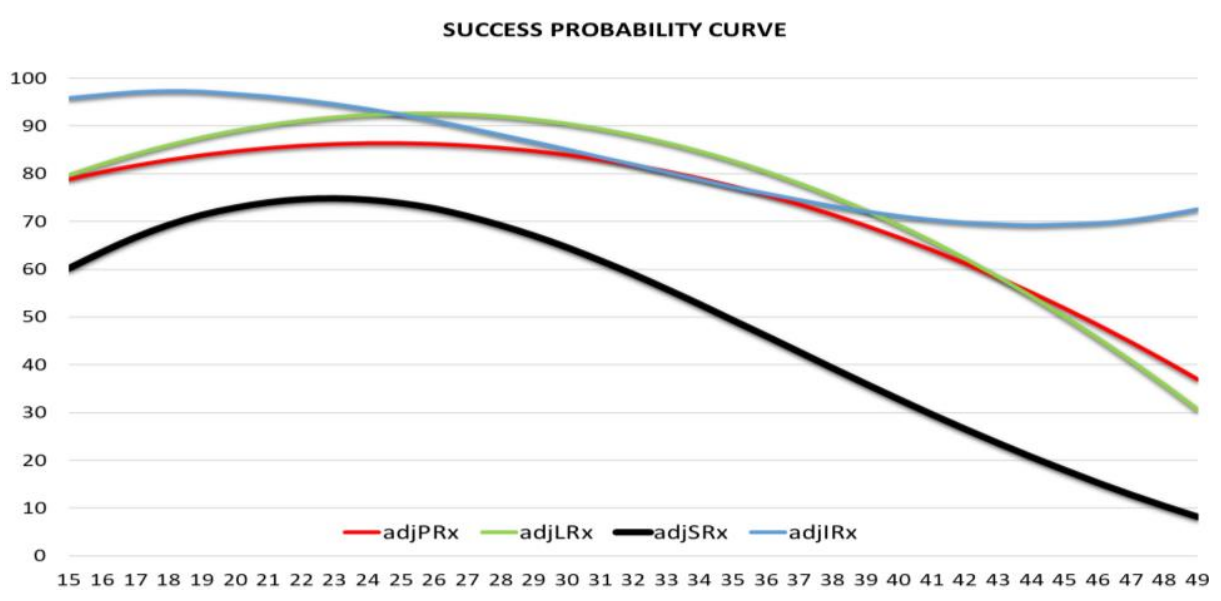

Fig. 2 Age-specific success rate $\left(\operatorname{adjSR}_{\mathrm{x}}\right)$

Equation 3 Adjusted age-specific success rate

$$
\operatorname{adjSR} R_{x}=\operatorname{adj} P R_{x} * \operatorname{adjIR} R_{x} \operatorname{adjLR} R_{x}
$$

\section{RESULTS}

The period data were extracted and calculated from the Demographic Yearbook of the Republic of Serbia, and the EUROSTAT fertility database. The number of live births by mother's age during the studied time period (Figure 3) shows a very symptomatic age pattern of fertility. During the 18-year time period the number of live births was "rotating" counterclockwise around the age of 30, leading to rapid decrease of birth from mothers below the age of 30, followed with much slower increase of births from mothers above that age. This change is so deep that in only 18 years the fertility peak shifted 6 years to the right, and the fertility rates of women aged $35+$ more than doubled. If this shift continues, in 12 years the fertility peak may shift to women outside of the optimal fertile group (20-34 years old).

Finally, we come to the main aim of the paper. If we consider live-births by mother's age as the result of the age-specific adjSRx, then we can come to the number of attempts, i.e. the number of women trying to get live-birth using the next equation.

Equation 4 Age-specific number of women trying to get a live-birth

$$
\operatorname{ATTEMPTS}_{x}=\left(N_{x} / \operatorname{adjSR}\right)_{x} * 100
$$

\footnotetext{
${ }^{3}$ Parabolic (quadratic) parameters for each smoothing are shown in Appendix 1.
} 


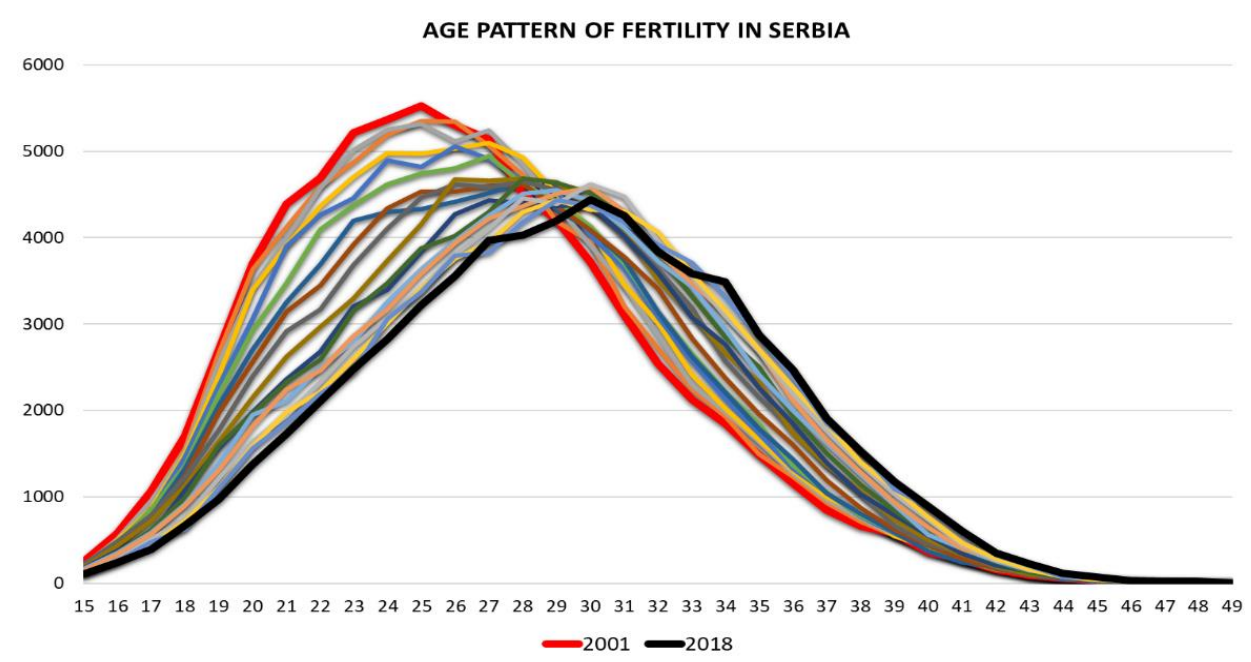

Fig. 3 Number of live births by mother's age in Serbia, 2001-2018

Now, if we compare the first and the last year of the observed period by two indicators (the number of live-births by the mother's age, and the number of women trying to get livebirth, also by age) we can see the whole strength of the age effect on the number of total live-births. The number of live-births decreased by $9574(-13.1 \%)$, but number of attempts decreased only by $2804(-2.5 \%)$, leading us to the conclusion that childbirth postponement decreased the weighted average of the success rate. Practically with a similar number of attempts, women in Serbia gave birth to a much smaller number of children due to decreasing probability of success, and increasing infertility with a woman's age.

During the whole observed time period the total number of women trying to get livebirth during one calendar year remained relatively stable, and ranged between 105915 in 2011 and 113545 in 2003 . With an average 109819 attempts during one calendar year, these values varied between $+3.4 \%$ and $-3.6 \%$ from the average. On the other hand, the total live-births ranged from 73621 in 2003 to 63778 in 2018, varying from $+7.7 \%$ to $6.7 \%$ relative to the average. The age effect actually doubled the differences between the first and the last year of the period. Actually, if we refer to the average natural $\operatorname{adjSRx}=0.6002(60,02 \%)^{4}$ then we can see that age pattern of fertility in Serbia was more favorable than natural fertility distribution until 2014. Thus, age effect was positive, and turned to negative from 2015 onwards. In other words, the age pattern of fertility affected average adjSRx, decreasing its values as childbirth postponement continued (Appendix 2).

\section{DISCUSSION}

In demography, the reproductive span of women includes ages between 15 and 49 . Obviously, this may not be the case in every individual person, but, based on large numbers we can notice that in modern societies more than $99 \%$ off all births occur within that age span. Medical findings say that majority of age-associated infertility problems in

\footnotetext{
${ }^{4}$ Natural weighted average SR for all ages of women between 15 and 49 in Serbia.
} 
women are related to ovarian aging (Liu and Case 2011). As a woman ages, so do her eggs. In other words, a woman's eggs are as old as herself. At the same time childbirth postponement is constantly widening the sexually active period of life with a high risk of reproductive health damage before realizing reproductive intentions.

If we refer to Serbian data, we can say that prevalence of effective contraception usage is very low, and the number of induced abortions has been very high for decades, even among medical professionals (Rašević and Sedlecki 2008, 2011; Rašević 2006, 2008a, 2008b). Presuming that the age one becomes sexually active is between 17 and 19, childbirth postponement over the last 30 years is so severe that the period of sexual activity before the birth of the first child almost doubled, doubling the risk of sexually transmitted diseases (STD-s), abortions, and other reproductive system complications. Potential fertility is shrinking with age, and it is well known that optimal the fertile age ranges between the ages of 20 and 35. WHO recommendations regarding fertility (WHO 2006; USAID 2007) say that women should not give birth before the age of 18, and not after the age of 35 . There are numerous reasons for such a claim. The reproductive system of women under 18 is not fully developed, and pregnancy and childbearing could cause severe complications for the mother, as well as for the child. In addition, early sexual activity, and especially early pregnancy can cause future reproductive system complications (Azevedo et al. 2012). On the other hand, giving birth after the age of 35 (advanced maternal age) is connected with a number of potentially negative biological and medical consequences. There are clear implications of birth delay, both for the mother and for the child (Bianco et al. 1996; Vohr et al. 2009). A higher incidence of spontaneous abortions, stillbirths, complications during pregnancy and preterm delivery, as well as an increased risk of fetal abnormality are just a few of them (Stein and Susser 2000). Due to childbirth postponement, a large number of women under 35 have accepted low family size norms, but most of them will eventually start reproduction. Nevertheless, we can expect that a certain share of these women in Serbia, for different reasons will not be able to realize the wanted norms pertaining to the desired number of children (Rašević 2006, 145). Lutz and Skirbekk in their paper "Policies Addressing the Tempo Effect in Low-Fertility Countries" emphasize that the current fertilitydepressing effect of an ongoing increase in the mean childbearing age will have a significant and lasting effect on population dynamics in Europe, played out in a population decline and accelerated population aging, the so-called "tempo effect" (Lutz and Skirbekk 2005). Modern European societies have already been facing sub-replacement fertility for several decades, and that is why the economic consequences are becoming so severe, reaching the point of non-sustainability for welfare states (Vasić and Marinković 2016, 159). Actually, there are two faces (effects) of low fertility in Europe: the tempo effect - women are delaying births to advanced ages, resulting in fewer births in the calendar years during which this delay happens, and the quantum effect - women are not having enough births to achieve replacement level. In fact, not all postponed births will be recuperated, and increases in the mean childbearing age tend to reduce the quantum of the fertility of the cohorts experiencing such increases (tempo-quantum interactions) (Lutz and Skirbekk 2005, 708).

Regarding childbirth postponement in Serbia, faced with the constant rise of MAB and change in the age pattern of fertility, the average SR was constantly shrinking, leading to an inevitable decrease of total live-births. If, hypothetically, such an age pattern change did not exist (from 2001 to 2018), regarding exact number of attempts during each year, the number of total live-births during this period would be 62746 higher. In other words, almost one whole generation was lost due to childbirth postponement. The 
MAB rise from 26,7 years in 2001 to 30,0 in 2018 reduced fertility by 5\%, and increased the number of unsuccessful attempts by 48436 due to age-related sterility, infertility and fetal loss.

\section{CONCLUSION}

Childbirth postponement is the most pronounced characteristic of fertility transition in the low fertility populations. Below replacement fertility ${ }^{5}$ phenomenon in Serbia (excluding data for Kosovo and Metohija) is now more than six decades old. Serbia has faced below replacement fertility for a whole decade before other European countries, even without fulfilling any of assumptions from the SDT. Many authors, doubt that Serbia (and other ex-Yugoslav countries) is experiencing shifts predicted by SDT as necessary preconditions for a long-lasting fertility decrease (Kuhar 2009; Bobić and Vukelić 2011; Vasić 2012), but such a long-term decrease is yet happening. In such conditions it is expected for fertility transition to take place at a fast and unpredictable pace. Many demographers called for urgent and systematic policy responses during the 1950s, but, as in many other European countries, the political response came only when the natural increase became negative (during the 1990s). If fertility policy had been introduced earlier, the demographic loss could potentially be smaller. The Birth Promotion Strategy of Republic of Serbia (Government of the Republic of Serbia 2018) points that incentives towards the earlier start of parenthood would be the most beneficial regarding fertility indicators and total live-births. Also, demographers recognized a clear relation between earlier first birth and higher completed fertility in Serbia (Rašević 2015), thus childbirth postponement must be identified as a significant target within fertility policy. Clear health and demographic benefits of an earlier parenting are reflected in age-related growth in infertility, especially after the age of 35 when SR falls below $50 \%$. It would be a matter of common sense striving to place conception attempts at an age that provides real chances for the successful realization of individual reproductive intentions, if those reproductive intentions really are a matter of essential life commitment.

Acknowledgement: This research is the result of previous work on the project Researching Demographic Phenomena for the Purpose of Public Policies in Serbia (47006) which was closed in 2019. and was financed by the Ministry of Education and Science of the Republic of Serbia.

\section{REFERENCES}

Azevedo, J. P. et al. Embarazo adolescente resumen. Washington, D.C.: World Bank Group, 2012. Available at: http://documents.worldbank.org/curated/en/2013/01/18612719/teenage-pregnancy-opportunities-latin-america

Beaujouan, E. and T. Sobotka. "Late motherhood in low-fertility countries: Reproductive intentions, trends and consequences". Human Fertility Database Research Report 002 (2017).

Bianco, A. et al. "Pregnancy outcome at age 40 and older". Obstetrics and Gynecology 87, 6 (1996): 917-922.

Bobić, M. i J. Vukelić. "Second Demographic Transition De-blocked?" Sociologija LIII, 2 (2011). doi:10.2298/SOC1102149B

Bongaarts, J. The Proximate Determinants of Natural Marital Fertility. NewYork: Population Council and Center for Policy Studies, 1982.

Demografska statistika. Beograd: Republički zavod za statistiku 2001-2018.

\footnotetext{
${ }^{5}$ The total fertility rate (TFR) below 2,1 children per woman.
} 
Dunson, D. B. et al. "Increased infertility with age in men and women". Obstetrics and Gynecology 103 (2004): 51-56.

Eijkemans, M. J. C. et al. "Too old to have children? Lessons from natural fertility populations". Human Reproduction 0, 0 (2014): 1-9. doi:10.1093/humrep/deu056

EUROSTAT Fertility Database. http://appsso.eurostat.ec.europa.eu/nui/show.do?dataset=demo_frate\&lang=en.

Ford, W. C. L. et al. "Increasing paternal age is associated with delayed conception in a large population of fertile couples: Evidence for declining fecundity in older men". Human Reproduction 15 (2000): 1703-1708.

Goldin, C. and L. F. Katz. "The power of the pill: Oral contraceptives and women's career and marriage decisions". Journal of Political Economy 110 (2002): 730-770.

Government of Republic of Serbia. Birth Promotion Strategy of Republic of Serbia. Beograd: Službeni glasnik RS 25, 2018

Hassan, M. A. M. and S.R. Killick. "Effect of male age on fertility: Evidence for the decline in male fertility with increasing age". Fertility and Sterility 79, 3 (2003): 1520-1527.

Jovanović-Batut, Milan. Prirodni prirast stanovništva Srbije i njegov biotički značaj. Beograd: Biblioteka centralnog higijenskog zavoda, 1932.

Kidd, S. A. et al. "Effects of male age on semen quality and fertility: A review of the literature". Fertil Steril 75 (2001): 237-248

Kuhar, M. "Da li su bivše jugoslovenske države države Druge Demografske Tranzicije“. U Porodice u Srbiji danas u komparativnoj perspektivi, uredile Milić i Tomanović. Beograd: ISI FF i Čigoja Štampa. 2009.

Leridon, H. "Can assisted reproduction technology compensate for the natural decline in fertility with age? A model assessment". Human Reproduction 19 (2004): 1548-1553.

Leridon, H. "A new estimate of permanent sterility by age: Sterility defined as the inability to conceive". Population Studies 62, 1 (2008): 15-24.

Liu, K. and A. Case. "Advanced Reproductive Age and Fertility." Journal of Obstetrics and Gynecology of Canada 269, 33 (2011): 1165-1175.

Lutz, W. and V. Skirbekk. "Policies addressing the tempo effect in low-fertility countries". Population and Development Review 31, 4 (2005): 699-720.

Nybo Andersen A. M. et al. "Maternal age and fetal loss: Population based register linkage study". $\mathrm{Br}$ Med J 320 (2000): $1708-1712$.

Pinborg, A. et al. "Influence of female body weight on IVF outcome including live birth rate - A longitudinal multi-centre cohort study of 487 infertile couples". RMB Online (2011).

Rašević, M. "Da li je evidentiran broj abortusa u Srbiji realan?" Stanovništvo XLVI, 2 (2008): 7-21.

Rašević, M. "Serbia: Transition from abortion to contraception or not?" Sociološki pregled XLII, 3 (2008): 295-305.

Rašević, M. i K. Sedlecki. "Pitanje postojanja abortusne culture u Srbiji”. Stanovništvo 49, 1 (2011): 1-13. doi:10.2298/STNV1101001R

Rašević, M. "Obrazovanje mladih za zaštitu reproduktivnog zdravlja". Zbornik Instituta za pedagoška istraživanja 38, 2 (2006): 472-485. doi: 10.2298/ZIPI0602472R

Rašević, M. "Fertilitet ženskog stanovništva" U Populacija Srbije početkom 21. veka, uredio Vladimir Nikitović. Beograd: Republički zavod za statistiku, 2015

Report of a WHO Technical Consultation on Birth Spacing. Geneva: WHO, 2006. [Online] Available at http://www.who.int/maternal_child_adolescent/documents/birth_spacing.pdf?ua=1

Schmidt, L. et al. "Demographic and medical consequences of the postponement of parenthood". Human Reproduction Update 18 (2012): 29-43.

Sedlecky, K. and M. Rašević. "Are Serbian gynecologists in line with modern family planning?" Eur $J$ Contracept Reprod Health Care 13 (2008): 158-163.

Stein, Z. and M. Susser. "The risks of having children later in life. Social advantage may make up for biological disadvantage". British Medical Journal 320, 7251 (2000): 1681-1682.

Steiner, A. Z. and A. M. Z. Jukic. "Impact of female age and nulligravidity on fecundity in an older reproductive age cohort". Fertil Steril 105 (2016): 1-6.

Uprava državne statistike. Statistički godišnjak Kraljevine Srbije, knjiga VII. Beograd: Državna štamparija Kraljevine Srbije. 1905.

USAID and ESD "HTSP 101: Everything You Want to Know About Healthy Timing and Spacing of Pregnancy. Washington DC, USAID, 2007. [Online] Available at http://www.who.int/pmnch/topics/maternal/htsp101.pdf

Van de Kaa, D. J. "On the societal impact of modern contraception". In The future of motherhood in Western societies. Late fertility and its consequences, edited by G. Beets, J. Schippers, and E. R. te Velde, 49-60. Berlin: Springer, 2011.

Vasić, P. "Koliko sociološke i ekonomske teorije mogu objasniti dugotrajni pad fertiliteta u Srbiji?" Demografija, knj. IX (2012): 237-256. 
Vasić, P. and I. Marinković. "Parental allowance in Serbia - Examining the world health organization recommendations". Transylvanian Review of Administrative Sciences 49E (2016): 150-168.

Vohr, B. R. et al. "Maternal age, multiple birth, and extremely low birth weight infants". Journal of Pediatrics 154, 4 (2009): 498-503.

Wesselink, A. K. et al. "Age and fecundability in a North American preconception cohort study". American Journal of Obstetrics and Gynecology 217. 667 (2017): 1-8. https://doi.org/10.1016/j.ajog.2017.09.002

Žene i muškarci u Republici Srbiji. Beograd: Republički zavod za statistiku. 2017.

\section{ODLAGANJE RAĐANJA I NEPLODNOST POVEZANA SA STAROŠĆU U SRBIJI}

Odlaganje rađanja je tema o kojoj se često raspravljalo još od 1990-ih, a na vrh demografske agende stavljena je pojavom paradigme Druge demografske tranzicije (DDT). Mehanizmi odlaganja rađanja koje su uglavnom objašnjavali ekonomisti ili sociolozi, shvatani su kao racionalne odluke pojedinaca (ili parova) koji pokušavaju da se usklade sa zahtevima modernog društva. Ovi mehanizmi su objašnjavani promenama dohotka i potrošnje (Becker, Modigliani) ili liberalnim i postmodernim vrednostima (Van de Kaa, Lestheage), dok se fiziološka ograničenja individualnog izbora uzrokovana starošću pojedinca gotovo uopšte nisu pominjala. Ova ograničenja koja nameće reproduktivni period ljudske vrste, bez izuzetka, utiču na sve koji pokušavaju da naprave optimalan reproduktivni izbor. Dva su glavna efekta odlaganja rađanja na broj živorođenja i stope fertiliteta. Prvi, kada parovi odlože rađanje deteta za stariju dob tokom određenog perioda, te se ostvari manji ukupan broj rađanja nego u odsustvu takvog odlaganja takozvani „tempo efekat" $i$ drugi, kao negativan efekat odlaganja rađanja na završni fertilitet $i$ povećan udeo žena bez i jednog živorođenja koji se pripisuje starosnom porastu neplodnosti. Ovaj drugi negativni efekat je upravo u fokusu našeg interesovanja. Pad završnog fertiliteta kohorte usled odlaganja rađanja uglavnom je proučavan na osnovu podataka o starosti majke na rođenju prvog deteta i sukcesivnom rađanju, kao i modela fekunditeta, pobačaja i vremena potrebnog za začeće prema starosti, koje ćemo pokušati da primenimo na podatke transferzalne demografske analize. Koristeći momentne podatke, pokušaćemo da kvantifikujemo potencijalni broj živorođenja koji bi se ostvario u hipotetičkom odsustvu odlaganja rađanja u Srbiji u protekle dve decenije.

Ključne reči: odlaganje rađanja, tempo fertiliteta, neplodnost, sterilitet, fetalni gubici, stopa uspešnosti. 